\title{
LXI. Notice of the geological features of a route from Madras to Bellary, in April and May 1822
}

\section{Capt. W. Cullen}

To cite this article: Capt. W. Cullen (1828) LXI. Notice of the geological features of a route from Madras to Bellary, in April and May 1822, Philosophical Magazine Series 2, 4:23, 355-363, DOI: $10.1080 / 14786442808674843$

To link to this article: http://dx.doi.org/10.1080/14786442808674843

册 Published online: 10 Jul 2009.

Submit your article to this journal $[\pi$

Џ Article views: 2

Q View related articles $\square$ 
LXI. Notice of the Geological Features of a Route from Madras to Bellary, in April and May 1822. By Capt.W. Cullen, of the East India Company's Artillery service*.

T BEG to submit to the Society an attempt to describe the geological features of a route which I lately passed over from Madras to Bellary. It accompanies a small collection of specimens of the prevalent rocks, and a barometrical section, which combined will, I hope, assist in affording some idea of the nature of the tracts in question.

The high road to Bellary was followed as far as Cuddapah; but from thence going north, by Chinnoor Nundialpett Poonnamila to Iddamacul, my route, from the last-mentioned village, lay nearly west by Giddeloor, over the Nulla Mulla range of hills by the Nundi Kunnuwi Ghaut + , by Banganapilly, Piaplee, and Gootty, to Bellary. A great proportion of this route must, in favourable weather, be as beantiful in point of scenery, as it is rich in geological interest; but at the period of my passing (the latter end of April and beginning of May), the excessive heat had checked all vegetation, and afforded but little inducement for excursions in quest of mineralogical specimens.

Referring the route to Arrowsmith's large map, which is sufficiently correct for the present purpose, it will be observed to offer an obvious distribution into five portions, each of them characterized by distinct geographical features.

First. The plain open tract from Madras to Naggery.

Second. The narrow mountainous belt extending from Naggery to the neighbourhood of Cummum.

"Iso, Leach. - Antenne gradually thickening from the base to near the apex, straight, bipectinated, or simple, with the interior edge subserrated : palpi short, not reaching beyond the clypens, densely clothed with scales: head, thorax, abdomen, and femora, thickly covered with scales, rather elongate on the former. Larva scaly, depressed; head small : pupa with long wing-cases."

"The species are known from the Anthoceræ ( $Z$ ygænæ) by the form of the Antennze, which are not curved, but nearly straight, and become gradually thicker as they approach the tip, which is again slightly attennated; the males have this part bipectinated, and the females simple, but serrated beneath; the species (of which there are several on the continent) are all of rich tints of light green, blue, or brownish, and immaculate."Illust. Brit. Ent. (Haustellata), vol. i.p. 105. Stephens gives only one species, (Statices, Linn.) as decidedly British : that considered as Globularic, Hubn. having, on examination, proved to be referable to Ino Statices, var. $\beta$. He conceives, however, that it is extremely probable that Ino Globularice may occur in England.

From the Transactions of the Literary Society of Madras. Part 1.

+ Kunnuwi is Kanarese for Ghat. Nundikunnuwi means, therefore, Nundi Ghat. 
Third. The open level country from the Nulla Mulla hills to Banaganapilly.

Fourth. The tract of tabular land between that town and Gootty.

Fifth. The level country from thence to Bellary.

The geological characters of this tract are equally remarkable, and admit of a division corresponding perfectly with its geographical features.

In the first division the prevailing rocks are granite.

In the second, clay-slate and sandstone.

In the third, compact blue limestone.

In the fourth, clay-slate and sandstone.

In the fifth, granitic.

I have ventured to characterize each division by one or two rocks only, because in each of them the rocks specified were, in general, beyond all comparison the most abundant. In the several divisions, of course, were found many of those minerals by which the principal rocks are usually accompanied; but to enumerate the whole of these as they occurred may not be deemed necessary, since the specimens themselves are forwarded.

Before entering into a detail of the rocks prevailing in these tracts, it may be proper to notice, in a general way, their absolute heights above the sea.

The north-west side of Pootoor, at the distance of sixtyfour miles from Madras, exclusive of windings, stands about 500 feet above the sea; exhibiting a rise of eight feet in the mile; and this proportion holds good throughout that part of the route, interrupted only by one undulation on the east side of Naggery, and by a second between Naggery and Pootoor.

These undulations, which rise 100 or 150 feet above the general level, nark the course of chains of hills, which in such places cross the road; and, in general, in all these sections of the terrepleine of a country, similar abrupt elevations may be considered as indications of the presence, and course of a chain of hills. There is a third rise a little beyond Pootoor, indicating like the former, the presence of a mountainous range.

The valley of Tripetty is, on a mean, about 360 feet above the sea, but the river which runs through its centre little above 300. The mean height of the valley from Baulpilly to Wuntimettah, an interval of about 52 miles, is about 550 feet, and the town of Cuddapah itself a little below 500 .

Chinnoor on the Pennar river, five or six miles north of Cuddapah, is about 30 feet lower than that place; but the

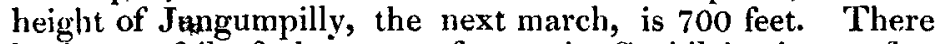
is then a fall of about 100 feet to the Saghilair river; after which it rises gradually to Alinuggar and Iddamacul, both of which 
which places are on the same level, about 900 feet above the sea. I was much disappointed in the height of the Nulla Mulla range, which, at the point where I crossed, did not attain an elevation of 1800 feet above the sea, and of little more, therefore, than 800 feet above the plains on either side.

The route across the plain, between the Nulla Mulla range and the table land at Banaganapilly, is nearly level, and about 800 feet above the sea; but the general declination of this plain appears to be from the Kistnah to the Pennar.

From Banaganapilly to Jeldroogum the ascent along the valley is pretty considerable, being 400 feet in about twenty iniles, or 20 feet per mile.

The table land, commencing two or three miles west of Jeldroogum, and extending to Piaplee, a distance of eight or ten miles, is between 1700 and 1800 feet above the sea*; and Colonel Lambton has already stated that to be the mean height of the country between Gootty and Bellaryt.

Although granitic have been mentioned as the prevailing rocks in the first division, none of them were seen in situ till about the thirty-seventh mile, in the bed of the river at the village of Nellatoor. The whole of the previous flat being a loose sandy soil, entirely free from rocky masses, añd even almost so of fragments, with the exception of some stony swells to the north of Cunkama Choultry. I should observe, however, that all the pagodas, facings of tanks, \&c., were built either of granite or laterite.

The blocks forming these latter have a rolled appearance, are a kind of coarse sandstone conglomerate or breccia, and perhaps originate from, or are connected with, the mountainchain running north from Naggery Nose. The granite, which first makes its appearance at Nellatoor, may be traced as far as Curcumbaddy, with no other interruption save that of those singular beds or courses of trap which are apparently so common in all the granitic tracts of this country. All these beds appear to run nearly east and west. In the present instance they were remarkably numerous, forming chains of low hills, and crossing the route so frequently, as to occupy a space which, taken in the aggregate, would nearly equal that of the granite itself. Granite, however, evidently composes the great mass of hills, which commence a few miles to the south-west

* But there is a very rapid descent from Piaplee towards Gootty, of 400 or 500 feet in the first ten miles. The plains west of Gootty are about 1200 feet above the sea.

+ This seenis rather under the truth:-barometrical observations, which I have since had an opportunity of making, give from 1400 to 1500 feet for the mean altitude of the country between Gootty and the Hoggree river, eight miles east of Bcllary. 
of Naggery, and which continuing near to the left of the road as far as Woramallipett, then stretch off to the west, till they are lost in the prolongation of the Tripetty range. The peculiar features of the granite are very marked and conspicuous in the whole of this western mass of hills, exhibiting itself on their slope, in those great bare masses of rock, which are so familiar to most people in this country, and on their summits in enormous detached rugged piles and fragments. But what contributes most powerfully to the interest of this part of the route are these singular courses or dykes of trap rocks, which may be observed crossing the country, without experiencing the smallest deviation or interruption in their course from the granitic barriers, which seem to oppose themselves on all hands to their progress.

Their deep black hue, and sharp, well-defined outline, contrasted with the light colour of the granite-masses, through and over which they seem to pass, forcibly arrest the attention. Granite appears also to a considerable distance on the right or north-east side of the road, and probably constitutes the greater portion of thevery remarkable hill called Naggery Nose, as I have traced it nearly to the foot of that hill. The hill just mentioned, however, as well as those immediately to the north of it, and whose outlines are equally singular, are evidently capped with rock of a different nature.

The caps, which occupy about one-fifth or one-sixth of the whole height of the hills, are precipitous and mural on their south and east sides, to the north sloping gradually off; until they fall almost into the same level with the plains. I attempted, both from Potoor and Woramullipett, to reach these hills, with the view of ascertaining their composition, but the distance was too great, and I could only approach their bases.

Judging from the external appearance of the cap, it is composed of two distinct rocks arranged in horizontal beds or strata. The upper and lower portion of it appeared to be of the same nature, being alike in colour, and marked by similar numerous, but irregular vertical seams and fissures; the effect, probably, of decomposition. The aspect of the central stratum or bed, was, however, different from either of those between which it lay. It was marked most distinctly throughout its whole extent, by regularly parallel and horizontal seams, which appeared to be those of stratification; its colour also, which was darker than the others, strengthening the supposition of its being a rock of a different nature*.

The

- I have since had an opportunity of examining the hills at Tripetty, where both the cap and slope of the hills appared to consist of but one rock. 
The western approach to these hills, for one mile and a half or two miles from their bases, was thickly strewed with nodules of several varieties of sandstone, the most common of which were of rather a close fine grain, sometimes so much so as hardly to be distinguished from quartz or hornstone. The finer-grained varieties were of different shades of red or brown, but generally of a light colour. There was also great abundance of a very coarse variety, composed of rounded pebbles, and fragments of quartz of all sizes, in the same specimen, from that of a pin's head to two or three inches in diameter, inbedded in a dark green basis. This variety was very remarkable. It was composed of rolled fragments and pebbles of quartz, which were generally of a white colour in a ground of dark green. The cement appears (on the march from Naggery to Potoor there were rolled masses of this variety twelve to eighteen inches diameter) to be hornblende, which communicating its tinge to the finer and transparent particles of quartz, affords a benutiful contrast to the large white pebbles imbedded in it. These nodules I should be disposed to trace from one or both of the two first-noticed portions of the cap, but I met with no fragments of any kind of schistus, owing perhaps to my not having approached sufficiently near. It has been noticed that the summits of this group of mountains, of which Naggery Nose forms the southernmost point, are mural and precipitous to the east and south, while to the north they fall gradually away, till they nearly coincide with the general level of the country. This latter appearance is very striking from Curcumbaddy, where the whole of that group is seen in reverse; Curcumbaddy itself being situated at the foot of one of these declivities, being a prolongation of the Tripetty range, which, from its outline and general aspect, I would infer to be of similar structure with that of Naggery.

The clay-slate, which occupies so great a portion of the subsequent route, first makes its appearance at Curcumbaddy; but the accumulation of sand and alluvial soil in the Tripetty valley, which is crossed on leaving Woramallipett, prevented my thus far tracing the continuity of the granite, although it is to be observed, with occasional beds of green-stone, in several parts of the road. The last rock I recollect to have passed before reaching Curcumbaddy was a bed of porphyritic greenstone, about one mile and a half or two miles from the village.

rock, and that sandstone. From this, and other corroborative instances on the route between Cuddapah and Ryachootee, I have little doubt that the caps of the Naggery range, of the great mass of hills east of that line, and, in short, of all the ranges exhibiting the same remarkable outlines, consist of varieties of sundstone or conglomerates.

The 
The granites of this division were generally of a light colour, shades of white and of a coarse texture; the darker varieties; however, inclining to brown or red, being, I think, the finer. grained.

The quartz and felspar were by far the most abundant constituents, and gave the colour to the rock; the hornblende, which was of a dark green, being very irregularly and sparingly distributed. There seemed to be little or no mica.

The texture of the trap was very uniform, and of a fine grain, composed distînctly of hornblende, and greenish white felspar.

The porphyritic variety, alluded to near Curcumbaddy, contained irregular crystals of felspar, of from one-tenth to five-tenths of an inch in diameter, of the same colour as the felspar of the basis.

The transition of clay-slate is very sudden and complete, The low hills immediately at the back of Curcumbaddy consist of a compact quartzose sandstone, or hornstone, but the clay-slate may be observed in contact with it, within 100 yards of the north side of the village. From this spot clayslate forms the grand and almost sole constituent; for, with the exception of occasional beds of calcareous schistus and flinty slate in the valleys and sandstone-caps on some of the hills, the great mass of the two singular mountain-chains which form the boundary of this interesting valley, on a line of upwards of 150 miles, appears to consist entirely of that rock. I must add, however, that should an actual personal examination of the strata be considered ipdispensable in subjects of this nature, these observations must of course, in such a case, be considered as only strictly applicable to the high road itself, or to a short distance on either hand.

'The seams of stratification are, however, so entirely regular' and distinct on the slope of the hills on either side, and in general so decidedly characteristic of these clay-slate tracts, that it is hardly possible to be mistaken in their nature, even at a distance of several miles. Towards the commencement, the hills are rather thickly clothed with wood; but on approaching Cuddapah, and all to the north of that plnce, the trees are stunted, and but thinly scattered over their sides, leaving, the strata-seams, like so many artificial terraces or ploughed furrows, distinctly exposed to yiew. The internal structure and colour of the slate, in a tract of such extent, were of course very various. At Curcumbaddy, and for a stage or two afterwards, chiefly shades of red; about Wuntimettah, purple and gray. Shades of these two last prevailed, I think, generally, till within eight miles south of Poonnamilla, 
when it suddenly altered to green; and this colour subsequently seemed to be constant in all the plains and low grounds. The general direction of the strata of clay-slate corresponded with that of the ranges of mountains which they composed; viz. about north-north-west and south-sonth-east, with a very great dip to the north-east; all the associated rocks being conformable, unless the sandstone-caps should be an exception, which appeared to have a very slight dip, if the appearances noticed from Curcumbaddy and Nundialpett may be considered as indications of it. However, of the latter I had few favourable opportunities for examination.

The strata of clay-slate appeared sometimes to be nearly vertical; but the exact dip was never measured.

The same dip and direction of the strata were exhibited in the fourth division, of clay-slate.

Of the rocks associated with clay-slate, the more important and general were sandstone, hornstone, calcareous schistus, flinty slate, and quartz. Calc-tufa, and marls of infinite variety of colour and induration were also found nearly throughout, and in some places in extraordinary quantity.

The sandstone was usually found on the summits of the hills; the calcareous schistus and flinty slate in the valleys; the quartz forming veins and layers in the seams of the clay-slate, and appearing therefore only where the latter was not concealed by alluvial depositions.

These were sometimes found all together; but it may be more convenient to consider each of them separately.

The quartz was generally of a white colour, and the layers of all degrees of thickness, from one tenth of an inch to one foot and a half. It was extremely subject to disintegration, covering the ground frequently in such quantity with its nodules, as completely to whiten it. These appearances were particularly remarkable on the march from Curcumbaddy to Baulpilly, from the vicinity of the hills on both flanks. Afterwards the valley opens, and the strata are generally concealed by the soil; but whenever rocks appear to any extent, quartz, either in veins or layers, will almost invariably be found pervading them. It is very abundant in the clay-slate between Nundaloor and Wuntimettah, and here rather remarkable from containing numerous little nests of a kind of green earth; until, however, fifty miles north of Cuddapah, and clearing the hills beyond Jungumpilly, the individual masses of quartz are too inconsiderable in themselves, to serve in any other way than merely as a characteristic of the clay-slate, and other more important rocks.

The march from Jungumpilly to Poornamila, with the exNew.Series. Vol, 4. No.23. Nov. $1828.3 \mathrm{~A}$ ception 
ception of the first five or six miles, is through an open level country, of perhaps fifteen miles square, as if it had been formed by the abstraction of a part of the central chain of hills which divide the southern and northern portions of this tract into two narrow valleys. The Saghilair river is crossed nearly in the centre of this open space; and it is immediately on reaching its northern bank that the quartz is observed to assume quite a new character, to constitute, as appears subsequently, one of the most important features in the remainder of the route.

A green schistus seems to prevail throughout this plain, and it continues as far north as Iddamacul, as may be observed from an examination of the wells; latterly also appearing above the surface in ridges of considerable elevation.

The strata of schistus in the bed of the Saghilair, which are nearly vertical, and of a bright green colour, present a very interesting appearance.

The direction of the strata at the ford corresponds with that of the bed of the river; and the stream, which appears subject to a very rapid rise and fall, has in consequence worn numerous deep narrow channels through the slate, presenting on all sides sharp perpendicular dykes of fifteen or twenty feet high, while they are often but a few inches in thickness. Almost immediately on reaching the north bank of the Saghilair, the quartz, which hitherto had never been met with but in the seams of the slate, and there seldom exceeding a breadth of eighteen inches, is now observed alone in immense blocks, and continuous masses, of fifty or sixty feet wide. Their direction corresponded, I think, generally with that of the strata of schistus, but they appeared above the soil unaccompanied by any other rock, and forming ridges of such magnitude and extent, as to give them the appearance of the summits of quartz hills, commencing to be denuded of soil, and forcibly impressing one with the idea of being in the vicinity of granite: nor was the impression, perhaps, altogether without foundation, as the small fort of Iddamacul, twenty miles further north, is built on an insulated hill of sienite.

The quartz ridges became gradually more numerous and extensive on my progress up the valley; but I lost them after leaving Iddamacul, and striking off to the westward by Giddeloor towards the Nulla Mulla range. Nothing could possibly be more interesting or striking than this small pile of sienitic masses, which, possessing all the peculiar rugged outline of a granitic hill, afforded the most singular contrast to the smooth, bare, undulated contour of the clay-slate ranges on either side of the valley. The valley was here seven or eight miles wide, and this hill rose out alone, as if forced up 
from below by volcanic agency, from the dead marshy flat in the centre of it. Its base might be 150 yards in diameter, and its perpendicular height about 100 feet. This sienite is composed of large crystals of black hornblende, and yellowish white felspar, very irregularly aggregated, with but little quartz, and that only in patches, and very unequally dispersed.

The sandstone which has been mentioned was usually found occupying the summits of the hills of clay-slate, and the opportunities, therefore, of actual examination were but rare. These opportunities occurred alsc at points very distant from each other, (but, perhaps, not the less corroborative from that circumstance, of the inference that the whole of these ranges are capped with varieties of sandstone,) viz. at Curcumbaddy, in the ghaut close to Baulpilly, in the passage through the range to Cuddapah, in the passage of the Nulla Mulla range, and lastly, in the fourth division, where, from the small elevation of the hills, these caps may be traced without the slightest interruption for upwards of five-and-twenty miles. The characters of the sandstone vary from that of a coarse conglomerate, such as that noticed on the route between Naggery and Pootoor, to that of the finest grain where it is difficult to distinguish it from quartz or hornstone, into both of which it seemed occasionally to pass. The colours were as various as the texture, being of all shades of red*, white, and green; some of the varieties met with on crossing the hills to Cuddapah were rather handsome.

The sandstone forming the cap of the Nulla Mulla hills, where I crossed them between Kistnumchettypitty and Madapurum, was of great thickness, about 300 feet perpendicular, and its acclivity on both sides, the route lying directly over it, extremely steep and difficult. A great deal of rock, much of the same nature as the cap, and interstratified with the clayslate, prevailed, however, for a space of three or four miles, on both sides of this central ridge, but the clay-slate still continuing by far the most abundant, and in deep wells immediately at the foot of the cap on the east and west sides, exhibiting that rock alone to the very bottom. The above-noticed were the chief occasions on which the sandstone was observed in extended masses; but nodules of that rock, as well as considerable apparently unconnected masses, were met with in several instances in the valleys, more particularly at the village of Chillumpett, between Codoor and Pollempettah, in the first part of the march from Nundaloor to Wuntimettah, between Poornamila and Alinaggur, in the ditch at Iddamacul, \&c.

[''o be continued.]

* The red varieties were most common, I think, west from Banaganapilly. 